\title{
Incidence of first primary central nervous system tumors in California, 2001-2005: children, adolescents and teens
}

\author{
Monica Brown · Rudolph Schrot • Katrina Bauer • \\ Jennifer Dodge
}

Received: 16 October 2008/Accepted: 16 March 2009/Published online: 2 April 2009

(c) The Author(s) 2009. This article is published with open access at Springerlink.com

\begin{abstract}
This study used data from the California Cancer Registry to comprehensively examine first primary central nervous system tumors (PCNST) by the International Classification of Childhood Cancers (ICCC) diagnostic groups and to compare their incidence by age groups, sex, race/ethnicity, socioeconomic status and tumor behavior. The study period, 2001-2005, represents the first 5 years of benign PCNST data collection in the state. The age-adjusted incidence rates were 2.1 for malignant and 1.3 for benign per 100,000. Children younger than 5 years old had the highest incidence of malignant PCNST (2.6 per 100,000). Teens aged 15-19 had the highest incidence of benign PCNST (1.8 per 100,000). Age-specific incidence rates were nearly the same for Hispanics, non-Hispanic whites, and Asian/Pacific Islanders for malignant PCNST
\end{abstract}

\section{Brown $(\bowtie) \cdot$ K. Bauer}

Public Health Institute/California Department of Public Health, Chronic Disease Surveillance and Research Branch, 1825 Bell

Street, Suite 102, Sacramento, CA 95825, USA

e-mail: MBrown@ccr.ca.gov; MonBrown@ucdavis.edu

K. Bauer

e-mail: KBauer@ccr.ca.gov

M. Brown

Division of Hematology and Oncology, Department of Internal Medicine, University of California at Davis, 4860 Y Street, Suite 3740, Sacramento, CA 95817, USA

R. Schrot

Department of Neurological Surgery, University of California at Davis, 4860 Y Street, Suite 3740, Sacramento, CA 95817, USA

e-mail: Rudolph.Schrot@ucdmc.ucdavis.edu

\section{J. Dodge}

Public Health Institute, Fresno, 1320 East Shaw Avenue,

Suite 160, Fresno, CA 93710, USA

e-mail: JDodge@phifresno.org among children younger than 5 (2.6-2.7 per 100,000); nonHispanic whites had the highest rates in the 5-14 year-old age group (2.5 per 100,000) and Asian/Pacific Islanders the highest among the 15-19 year old age group (2.3 per $100,000)$. We found no statistically significant differences in the incidence of malignant PCNST by race/ethnicity in any age group. Astrocytoma had the highest incidence for both malignant and benign histology in most age groups.

Keywords Brain and other central nervous system neoplasms · Epidemiology · Cancer incidence . Childhood cancers $\cdot$ Ethnic groups

\section{Introduction}

Primary tumors of the central nervous system (PCNST) among children, adolescents, and teens differ from those in adults in frequency, histological appearance, and clinical behavior [1]. PCNST are the second most common form of cancer among children aged 15 years and younger and the third most common among those 15-19 years old in California. While PCNST represent only $1.3 \%$ of incident cancers among adults 20 years and older, they represent from $26.4 \%$ (5-9 year olds) to $9.5 \%$ (15-19 year olds) of incident cancers among persons younger than 20 years old [2]. PCNST are the second leading cause of cancer deaths among children younger than 15 years old; they cause 32\% (5-9 year olds) and 12.1\% (15-19 year olds) of cancer deaths in children compared to $3 \%$ of cancer deaths for adults 20 years and older [2]. PCNST among children, adolescents, and teens tend to have short latent periods, often grow rapidly, and are aggressively invasive [1]. PCNST are a significant public health problem, they have a far more devastating effect on society, 
communities and considering the potential years of productive life lost [3].

This study examined the incidence of malignant and benign first PCNST among children, adolescents, and teens using the population-based California Cancer Registry (CCR) from 2001 to 2005 . This population is a subset of the population described in the authors' companion publication in this edition. Since 1988, California state law mandates the reporting of all newly diagnosed malignant cancers in California [4]. An amendment to this law enacted January 2001 provides for the additional reporting of benign and borderline behavior PCNST [5]. The 2001-2005 study period represents the first 5 years of complete PCNST data collection in California. The CCR provides a robust source of epidemiologic data for a densely populous geographic area. California can be viewed as a microcosm of United States reflecting the influence of its racial, ethnic and sociodemographic diversity on overall cancer incidence. Although pediatric PCNST incidence has been relatively well studied, this is the first study to comprehensively examine PCNST incidence by patient demographics and tumor behavior among children, adolescents and teens according to the International Classification of Childhood Cancers (ICCC).

\section{Materials and methods}

Materials and methods, including case identification, inclusion/exclusion criteria and tumor behavior assignment used in this study were identical to those described in the authors' companion publication in this edition. For these analyses, we divided cases into 4 age groups. Patients younger than 5 and patients 5-9 years old are referred to as children, those aged 10-14 years as adolescents, and those 15-19 years old as teens. Diagnostic groups were organized using the Surveillance, Epidemiology and End Results (SEER) Program's site/histology modification to the ICCC [6, 7]. Table 1 lists ICCC diagnostic groups by

Table 1 SEER recode of ICCC diagnostic groups and ICD-O-3 codes for California cases, 2001-2005

\begin{tabular}{|c|c|c|c|}
\hline \multicolumn{2}{|c|}{ Diagnostic groups } & \multicolumn{2}{|l|}{ ICD-O-3 code(s) } \\
\hline & & Morphology & Topography \\
\hline IIIA & $\begin{array}{l}\text { Ependymomas \& choroid } \\
\text { plexus tumor }\end{array}$ & $9383,9390-9394,9390$ & $\mathrm{C} 000-\mathrm{C} 809$ \\
\hline \multirow[t]{2}{*}{ IIIB } & \multirow[t]{2}{*}{ Astrocytomas } & 9380 & C723 \\
\hline & & $\begin{array}{l}9384,9400,9401,9410,9411,9420,9421, \\
\quad 9423,9424,9440-9442\end{array}$ & $\mathrm{C} 000-\mathrm{C} 809$ \\
\hline IIIC1 & Medulloblastomas & $9470-9472,9474,9480$ & C000-C809 \\
\hline IIIC2 & $\begin{array}{l}\text { Primitive neuroectodermal } \\
\text { tumors (PNET) }\end{array}$ & 9473 & $\mathrm{C} 000-\mathrm{C} 809$ \\
\hline \multirow[t]{2}{*}{ IIIC9 } & \multirow{2}{*}{$\begin{array}{l}\text { Other intracranial \& } \\
\text { intraspinal embryonal } \\
\text { tumors }\end{array}$} & $9501-9503$ & C700-C729 \\
\hline & & 9508 & $\mathrm{C} 000-\mathrm{C} 809$ \\
\hline \multirow[t]{2}{*}{ IIID } & \multirow[t]{2}{*}{ Other gliomas } & 9380 & $\begin{array}{l}\text { C700-C722, C724- } \\
\text { C729, C751, C753 }\end{array}$ \\
\hline & & $9381,9382,9430,9450,9451,9460$ & $\mathrm{C} 000-\mathrm{C} 809$ \\
\hline IIIE & $\begin{array}{l}\text { Other specified intracranial \& } \\
\text { intraspinal neoplasms }\end{array}$ & $\begin{array}{c}8270-8281,8300,9350-9352,9360-9362,9412,9413, \\
9492,9493,9505-9507,9530-9537,9537-9539\end{array}$ & $\mathrm{C} 000-\mathrm{C} 809$ \\
\hline XA & $\begin{array}{l}\text { Intracranial \& intraspinal } \\
\text { germ cell tumors }\end{array}$ & 9060, 9064, 9065, 9070-9072, 9080-9085, 9100 & $\begin{array}{l}\mathrm{C} 700-\mathrm{C} 729 \\
\mathrm{C} 751-\mathrm{C} 753\end{array}$ \\
\hline \multirow[t]{3}{*}{ Z } & \multirow[t]{3}{*}{ Other } & $8000-8005,9370$ & $\begin{array}{l}\text { C700-C729, } \\
\text { C751-C753 }\end{array}$ \\
\hline & & $9501-9503$ & $\begin{array}{l}\text { C000-C699, } \\
\text { C739-C768, C809 }\end{array}$ \\
\hline & & $\begin{array}{l}8680,8728,8810,8850,8920,9120,9121,9130,9150,9161, \\
\quad 9260,9490,9500,9522,9523,9540-9571,9590,9591,9650,9670, \\
\quad 9671,9675,9680,9684,9687,9690,9691,9695,9698,9699,9702,9705, \\
9714,9719,9727-9729,9731,9733,9734,9740,9741,9750\end{array}$ & $\mathrm{C} 000-\mathrm{C} 809$ \\
\hline
\end{tabular}

SEER Surveillance, Epidemiology and End Results

ICCC International Classification of Childhood Cancers, 3rd edition

ICD International Classification of Diseases, Oncology, 3rd edition 
International Classification Diseases, Oncology, 3rd edition's (ICD-O-3) morphology and topography codes.

\section{Results}

There were 2,096 cases of PCNST among children, adolescents, and teens (from birth to 19 years old) in California from 2001 to 2005. Of those cases, 1,114 $(53.1 \%)$ were malignant, $698(33.3 \%)$ were benign, and $284(13.6 \%)$ were of uncertain behavior. The resultant AAIR per 100,000 was 2.1 (CI: 2.0-2.2) for malignant, 1.3 (CI: 1.2-1.4) for benign, and 0.5 (CI: $0.5-0.6)$ for tumors of uncertain behavior.

As seen in Table 2, there was an increase in the proportion of cases by year for tumors of uncertain behavior for adolescents and teens, whereas the proportion of cases among the two groups of children, for both malignant and benign PCNST, appears to be stable over the study period. The ASIR for malignant PCNST decreased as age increased, starting from 2.6 per 100,000 among those younger than 5 years to 1.7 per 100,000 among 15 to 19 year olds. To compare with other studies, we calculated the AAIR per 100,000 for children and adolescents to be 2.2 for malignant and 1.2 for benign PCNST. The ASIR for benign PCNST fluctuated by age groups, ranging from 1.8 to 1.1 per 100,000 . The incidence of tumors of uncertain behavior was very low. The pattern seen for malignant PCNST by age group was opposite that for tumors of

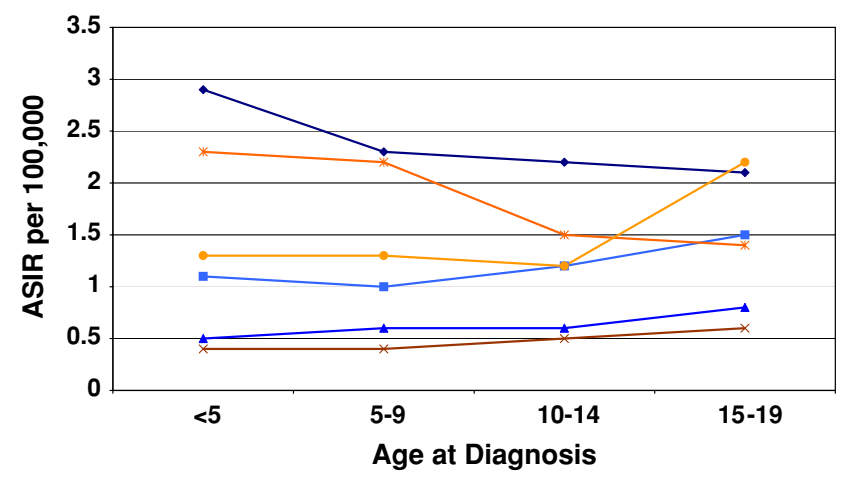

$\multimap$ Male, Malignant $\rightarrow$ Male, Benign $\quad$ Female, Malignant $\sim$ Female, Benign $\rightarrow$ Male, Uncertain $\multimap$ Female, Uncertain

Fig. 1 Age-specific incidence rates (ASIR) of first primary malignant and benign first primary central nervous system tumors by age group and sex, California, 2001-2005

uncertain behavior. Incident rates increased slightly as age group increased.

The highest incidence of PCNST was for malignant tumors in children and adolescents (Fig. 1). This pattern changed for teens, where incidence of benign PCNST was similar to that of malignant PCNST. The lowest incidence, at every age group, was for tumors of uncertain behavior. The ASIR for boys for malignant and uncertain behavior PCNST were higher than that for girls at all age groups. Incidence rates for girls with benign PCNST were higher than that for boys until adolescence, where they appeared

Table 2 Number of cases, percent and age-specific incidence rate* (ASIR) of first primary central nervous system tumors by age group, tumor behavior and year of diagnosis, California, 2001-2005

\begin{tabular}{|c|c|c|c|c|c|c|c|c|c|c|c|c|c|c|}
\hline \multirow[t]{2}{*}{ Age group } & \multirow[t]{2}{*}{ Behavior } & \multicolumn{2}{|c|}{2001} & \multicolumn{2}{|c|}{2002} & \multicolumn{2}{|c|}{2003} & \multicolumn{2}{|c|}{2004} & \multicolumn{2}{|c|}{2005} & \multicolumn{3}{|c|}{ Total } \\
\hline & & $n$ & $\%$ & $n$ & $\%$ & $n$ & $\%$ & $n$ & $\%$ & $n$ & $\%$ & $n$ & $\%$ & ASIR 95\%CI \\
\hline \multirow[t]{4}{*}{$<5$ years } & Malignant & 65 & 19.2 & 73 & 21.5 & 67 & 19.8 & 58 & 17.1 & 76 & 22.4 & 339 & 100.0 & $2.6(2.4,2.9)$ \\
\hline & Benign & 34 & 22.1 & 29 & 18.8 & 34 & 22.1 & 33 & 21.4 & 24 & 15.6 & 154 & 100.0 & $1.2(1.0,1.4)$ \\
\hline & Uncertain & 11 & 20.4 & 14 & 25.9 & 7 & 13.0 & 11 & 20.4 & 11 & 20.4 & 54 & 100.0 & $0.4(0.3,0.5)$ \\
\hline & Total & 110 & 20.1 & 116 & 21.2 & 108 & 19.7 & 102 & 18.6 & 111 & 20.3 & 547 & 100.0 & $4.2(3.9,4.6)$ \\
\hline \multirow[t]{4}{*}{ 5-9 years } & Malignant & 70 & 23.6 & 59 & 19.9 & 61 & 20.5 & 53 & 17.8 & 54 & 18.2 & 297 & 100.0 & $2.3(2.0,2.5)$ \\
\hline & Benign & 28 & 18.9 & 30 & 20.3 & 37 & 25.0 & 30 & 20.3 & 23 & 15.5 & 148 & 100.0 & $1.1(1.0,1.3)$ \\
\hline & Uncertain & 7 & 10.8 & 13 & 20.0 & 15 & 23.1 & 14 & 21.5 & 16 & 24.6 & 65 & 100.0 & $0.5(0.4,0.6)$ \\
\hline & Total & 105 & 20.6 & 102 & 20.0 & 113 & 22.2 & 97 & 19.0 & 93 & 18.2 & 510 & 100.0 & $3.9(3.6,4.3)$ \\
\hline \multirow[t]{4}{*}{ 10-14 years } & Malignant & 49 & 19.2 & 60 & 23.5 & 46 & 18.0 & 53 & 20.8 & 47 & 18.4 & 255 & 100.0 & $1.9(1.6,2.1)$ \\
\hline & Benign & 23 & 14.4 & 34 & 21.3 & 33 & 20.6 & 29 & 18.1 & 41 & 25.6 & 160 & 100.0 & $1.2(1.0,1.4)$ \\
\hline & Uncertain & 15 & 19.7 & 11 & 14.5 & 14 & 18.4 & 12 & 15.8 & 24 & 31.6 & 76 & 100.0 & $0.6(0.4,0.7)$ \\
\hline & Total & 87 & 17.7 & 105 & 21.4 & 93 & 18.9 & 94 & 19.1 & 112 & 22.8 & 491 & 100.0 & $3.6(3.3,3.9)$ \\
\hline \multirow[t]{4}{*}{ 15-19 years } & Malignant & 37 & 16.6 & 45 & 20.2 & 34 & 15.2 & 60 & 26.9 & 47 & 21.1 & 223 & 100.0 & $1.7(1.5,2.0)$ \\
\hline & Benign & 41 & 17.4 & 46 & 19.5 & 45 & 19.1 & 50 & 21.2 & 54 & 22.9 & 236 & 100.0 & $1.8(1.6,2.1)$ \\
\hline & Uncertain & 14 & 15.7 & 17 & 19.1 & 18 & 20.2 & 20 & 22.5 & 20 & 22.5 & 89 & 100.0 & $0.7(0.6,0.8)$ \\
\hline & Total & 92 & 16.8 & 108 & 19.7 & 97 & 17.7 & 130 & 23.7 & 121 & 22.1 & 548 & 100.0 & $4.2(3.9,4.6)$ \\
\hline
\end{tabular}

* Age-specific incidence rates are per 100,000 population. Rates are standardized to the 2000 US population 
Table 3 Number of cases and percent of first primary central nervous system tumors, by age group, population demographic characteristics and tumor behavior, California, 2001-2005
Shaded cells categories with less than 5 cases were omitted

\begin{tabular}{|c|c|c|c|c|c|c|c|c|c|c|}
\hline \multirow{2}{*}{\multicolumn{3}{|c|}{ Demographic Characteristics }} & \multirow{2}{*}{\multicolumn{2}{|c|}{ Malignant }} & \multirow{2}{*}{\multicolumn{2}{|c|}{ Benign }} & \multirow{2}{*}{\multicolumn{2}{|c|}{ Uncertain }} & \multirow{2}{*}{\multicolumn{2}{|c|}{ Total }} \\
\hline & & & & & & & & & & \\
\hline \multirow{13}{*}{$\begin{array}{l}<5 \\
\text { years }\end{array}$} & Sex & Male & 193 & $56.9 \%$ & 72 & $46.8 \%$ & 30 & $55.6 \%$ & 295 & $53.9 \%$ \\
\hline & & Female & 146 & $43.1 \%$ & 82 & $53.2 \%$ & 24 & $44.4 \%$ & 252 & $46.1 \%$ \\
\hline & Race/ethnicity & Non-Hispanic white & 108 & $31.9 \%$ & 62 & $40.3 \%$ & 23 & $42.6 \%$ & 193 & $35.3 \%$ \\
\hline & & Non-Hispanic black & 21 & $6.2 \%$ & 8 & $5.2 \%$ & & & 32 & $5.9 \%$ \\
\hline & & Hispanic & 168 & $49.6 \%$ & 69 & $44.8 \%$ & 25 & $46.3 \%$ & 262 & $47.9 \%$ \\
\hline & & Asian-Pacific Islander & 37 & $10.9 \%$ & 11 & $7.1 \%$ & & & 50 & $9.1 \%$ \\
\hline & & Other/Unknown & 5 & $1.5 \%$ & & & & & 10 & $1.8 \%$ \\
\hline & Socioeconomic & Low & 147 & $43.4 \%$ & 72 & $46.8 \%$ & 27 & $50.0 \%$ & 246 & $45.0 \%$ \\
\hline & Status & Medium & 62 & $18.3 \%$ & 29 & $18.8 \%$ & 12 & $22.2 \%$ & 103 & $18.8 \%$ \\
\hline & & High & 130 & $38.3 \%$ & 53 & $34.4 \%$ & 15 & $27.8 \%$ & 198 & $36.2 \%$ \\
\hline & Level of & Urban & 325 & $95.9 \%$ & 144 & $93.5 \%$ & 50 & $92.6 \%$ & 519 & $94.9 \%$ \\
\hline & Urbanization & Rural & 14 & $4.1 \%$ & 10 & $6.5 \%$ & & & 28 & $5.1 \%$ \\
\hline & Total & & 339 & & 154 & & 54 & & 547 & \\
\hline \multirow{13}{*}{$\begin{array}{l}5-9 \\
\text { years }\end{array}$} & Sex & Male & 155 & $52.2 \%$ & 68 & $45.9 \%$ & 39 & $60.0 \%$ & 262 & $51.4 \%$ \\
\hline & & Female & 142 & $47.8 \%$ & 80 & $54.1 \%$ & 26 & $40.0 \%$ & 248 & $48.6 \%$ \\
\hline & Race/ethnicity & Non-Hispanic white & 113 & $38.0 \%$ & 74 & $50.0 \%$ & 25 & $38.5 \%$ & 212 & $41.6 \%$ \\
\hline & & Non-Hispanic black & 17 & $5.7 \%$ & 9 & $6.1 \%$ & & & 28 & $5.5 \%$ \\
\hline & & Hispanic & 138 & $46.5 \%$ & 55 & $37.2 \%$ & 30 & $46.2 \%$ & 223 & $43.7 \%$ \\
\hline & & Asian-Pacific Islander & 24 & $8.1 \%$ & 8 & $5.4 \%$ & 8 & $12.3 \%$ & 40 & $7.8 \%$ \\
\hline & & Other/Unknown & 5 & $1.7 \%$ & & & 0 & $0.0 \%$ & 7 & $1.3 \%$ \\
\hline & Socioeconomic & Low & 134 & $45.1 \%$ & 52 & $35.1 \%$ & 31 & $47.7 \%$ & 217 & $42.5 \%$ \\
\hline & Status & Medium & 53 & $17.8 \%$ & 34 & $23.0 \%$ & 11 & $16.9 \%$ & 98 & $19.2 \%$ \\
\hline & & High & 110 & $37.0 \%$ & 62 & $41.9 \%$ & 23 & $35.4 \%$ & 195 & $38.2 \%$ \\
\hline & Level of & Urban & 283 & $95.3 \%$ & 138 & $93.2 \%$ & 61 & $93.8 \%$ & 482 & $94.5 \%$ \\
\hline & Urbanization & Rural & 14 & $4.7 \%$ & 10 & $6.8 \%$ & & & 28 & $5.5 \%$ \\
\hline & Total & & 297 & & 148 & & 65 & & 510 & \\
\hline \multirow{13}{*}{$\begin{array}{l}10-14 \\
\text { years }\end{array}$} & Sex & Male & 154 & $60.4 \%$ & 82 & $51.3 \%$ & 43 & $56.6 \%$ & 279 & $56.8 \%$ \\
\hline & & Female & 101 & $39.6 \%$ & 78 & $48.8 \%$ & 33 & $43.4 \%$ & 212 & $43.2 \%$ \\
\hline & Race/ethnicity & Non-Hispanic white & 113 & $44.3 \%$ & 78 & $48.8 \%$ & 33 & $43.4 \%$ & 224 & $45.6 \%$ \\
\hline & & Non-Hispanic black & 10 & $3.9 \%$ & 10 & $6.3 \%$ & 8 & $10.5 \%$ & 28 & $5.7 \%$ \\
\hline & & Hispanic & 104 & $40.8 \%$ & 61 & $38.1 \%$ & 31 & $40.8 \%$ & 196 & $39.9 \%$ \\
\hline & & Asian-Pacific Islander & 27 & $10.6 \%$ & 6 & $3.8 \%$ & & & 37 & $7.5 \%$ \\
\hline & & Other/Unknown & & & 5 & $3.1 \%$ & 0 & $0.0 \%$ & 6 & $1.2 \%$ \\
\hline & Socioeconomic & Low & 104 & $40.8 \%$ & 58 & $36.3 \%$ & 37 & $48.7 \%$ & 199 & $40.5 \%$ \\
\hline & Status & Medium & 42 & $16.5 \%$ & 35 & $21.9 \%$ & 10 & $13.2 \%$ & 87 & $17.7 \%$ \\
\hline & & High & 109 & $42.7 \%$ & 67 & $41.9 \%$ & 29 & $38.2 \%$ & 205 & $41.8 \%$ \\
\hline & Level of & Urban & 243 & $95.3 \%$ & 151 & $94.4 \%$ & 69 & $90.8 \%$ & 28 & $5.7 \%$ \\
\hline & Urbanization & Rural & 12 & $4.7 \%$ & 9 & $5.6 \%$ & 7 & $9.2 \%$ & 463 & $94.3 \%$ \\
\hline & Total & & 255 & & 160 & & 76 & & 491 & \\
\hline \multirow{13}{*}{$\begin{array}{l}15-19 \\
\text { years }\end{array}$} & Sex & Male & 138 & $61.9 \%$ & 101 & $42.8 \%$ & 52 & $58.4 \%$ & 291 & $53.1 \%$ \\
\hline & & Female & 85 & $38.1 \%$ & 135 & $57.2 \%$ & 37 & $41.6 \%$ & 257 & $46.9 \%$ \\
\hline & Race/ethnicity & Non-Hispanic white & 102 & $45.7 \%$ & 105 & $44.5 \%$ & 40 & $44.9 \%$ & 247 & $45.1 \%$ \\
\hline & & Non-Hispanic black & 12 & $5.4 \%$ & 9 & $3.8 \%$ & 7 & $7.9 \%$ & 28 & $5.1 \%$ \\
\hline & & Hispanic & 73 & $32.7 \%$ & 103 & $43.6 \%$ & 36 & $40.4 \%$ & 212 & $38.7 \%$ \\
\hline & & Asian-Pacific Islander & 35 & $15.7 \%$ & 17 & $7.2 \%$ & 5 & $5.6 \%$ & 57 & $10.4 \%$ \\
\hline & & Other/Unknown & & & & & & & & \\
\hline & Socioeconomic & Low & 85 & $38.1 \%$ & 105 & $44.5 \%$ & 32 & $36.0 \%$ & 222 & $40.5 \%$ \\
\hline & Status & Medium & 42 & $18.8 \%$ & 49 & $20.8 \%$ & 16 & $18.0 \%$ & 107 & $19.5 \%$ \\
\hline & & High & 96 & $43.0 \%$ & 82 & $34.7 \%$ & 41 & $46.1 \%$ & 219 & $40.0 \%$ \\
\hline & Level of & Urban & 207 & $92.8 \%$ & 223 & $94.5 \%$ & 81 & $91.0 \%$ & 511 & $93.2 \%$ \\
\hline & Urbanization & Rural & 16 & $7.2 \%$ & 13 & $5.5 \%$ & 8 & $9.0 \%$ & 37 & $6.8 \%$ \\
\hline & Total & & 223 & & 236 & & 89 & & 548 & \\
\hline
\end{tabular}

dramatically from 5 to 14 years old; incidence rates for boys declined as well but not as dramatically. When PCNST incidence rates were compared by age group, sex, and tumor behavior, we found that there were no significant 
differences except among adolescents. The ASIR for malignant PCNST for adolescent boys was 2.2 (CI: 1.92.6) and for adolescent girls was 1.5 (CI: 1.2-1.8). Malignant PCNST incidence among teen boys and girls was 2.1 (CI: 1.7-2.5) and 1.4 (CI: 1.1-1.7), respectively. Benign PCNST among teen boys and girls was 1.5 (CI: $1.2-1.8$ ) and 2.2 (CI: 1.8-2.6), respectively.

Table 3 shows the study population by age groups, demographic characteristics, and tumor behavior. For nearly all age groups, boys were more often diagnosed with malignant PCNST and tumors of uncertain behavior; girls, proportionally, had more benign PCNST. The exception was for adolescents, where boys were proportionally diagnosed more often with benign PCNST.

Hispanic children, younger than 5 , had proportionally more PCNST. Non-Hispanic white adolescents and teens had proportionally more PCNST. In the 5-9 age group, Hispanic children had more malignant and uncertain behavior PCNST while non-Hispanic white children had more benign PCNST.

Among children younger than 5, more cases were from lower socioeconomic status (SES) regardless of tumor behavior. For children 5-9, more cases of malignant and uncertain PCNST were in low SES, while benign cases were from high SES. For adolescents and teens, all cases of malignant PCNST were from high SES. For adolescents, more benign cases were from high SES while uncertain cases were from low SES. For teens, the opposite was seen-more uncertain cases were from high SES while more benign cases were from low SES. Lastly, overwhelmingly, more cases, regardless of tumor behavior were from urban areas of California than from rural.

Incidence rates were calculated for race/ethnic groups by tumor behavior in Table 4 . For many subgroups by age, race/ethnicity, or tumor behavior, incidence rates could not be calculated due to the small number of cases. Where incidence rates could be calculated and compared, we found no statistically significant differences by race/ethnicity for any age group by tumor behavior. Incidence rates for all tumor behaviors were highest in non-Hispanic white children aged 5-9 years and in adolescents with the exception of malignant tumors, which were highest in Asian/Pacific Islander children younger than 5 and teens.

At every age group, astrocytomas (IIIB), ependymomas, and choroid plexus (IIIA) predominated (Table 5). For both malignant and benign PCNST, at nearly every age group, astrocytoma had the highest incidence. Among children younger than 5 years old, the primary malignant diagnoses were ependymomas and choroid plexus (IIIA), while for children 5-9 years old, other gliomas (IIID) was
Table 4 Age-specific incidence rate $^{\mathrm{a}}$ (ASIR) with $95 \%$ confidence interval (CI) of first primary central nervous system tumors by age group, tumor behavior and race/ethnicity, California, 2001-2005 a Age-specific incidence rates are per 100,000 population. Rates are standardized to the 2000 US population

Shaded cells rates could not be calculated if number of cases were less than 15 and/or the underlying population was less than 100,000

\begin{tabular}{|c|c|c|c|}
\hline \multirow[t]{2}{*}{ Age Group } & \multirow[t]{2}{*}{ Race } & Malignant & Benign \\
\hline & & ASIR $\quad 95 \% \mathrm{Cl}$ & ASIR $\quad 95 \% \mathrm{Cl}$ \\
\hline \multirow[t]{5}{*}{$<5$ years } & Non-Hispanic White & $2.6(2.2,3.2)$ & $1.5(1.2,1.9)$ \\
\hline & Non-Hispanic Black & $2.3(1.4,3.5)$ & \\
\hline & Hispanic & $2.6(2.2,3.0)$ & $1.1(0.8,1.4)$ \\
\hline & Asian-Pacific Islander & $2.7(1.9,3.8)$ & \\
\hline & Total & $2.6(2.4,2.9)$ & $1.2(1.0,1.4)$ \\
\hline \multirow[t]{5}{*}{$5-9$ years } & Non-Hispanic White & $2.5(2.1,3.1)$ & $1.7(1.3,2.1)$ \\
\hline & Non-Hispanic Black & $1.7(1.0,2.8)$ & \\
\hline & Hispanic & $2.2(1.9,2.6)$ & $0.9(0.7,1.2)$ \\
\hline & Asian-Pacific Islander & $1.8(1.1,2.6)$ & \\
\hline & Total & $2.3(2.0,2.5)$ & $1.1(1.0,1.3)$ \\
\hline \multirow[t]{5}{*}{$10-14$ years } & Non-Hispanic White & $2.3(1.9,2.7)$ & $1.6(1.2,1.9)$ \\
\hline & Non-Hispanic Black & & \\
\hline & Hispanic & $1.7(1.4,2.1)$ & $1.0(0.8,1.3)$ \\
\hline & Asian-Pacific Islander & $1.8(1.2,2.7)$ & \\
\hline & Total & $1.9(1.6,2.1)$ & $1.2(1.0,1.4)$ \\
\hline \multirow[t]{5}{*}{$15-19$ years } & Non-Hispanic White & $2.0(1.6,2.5)$ & $2.1(1.7,2.5)$ \\
\hline & Non-Hispanic Black & & \\
\hline & Hispanic & $1.4(1.1,1.8)$ & $2.0(1.6,2.4)$ \\
\hline & Asian-Pacific Islander & $2.3(1.6,3.2)$ & $1.1(0.7,1.8)$ \\
\hline & Total & $1.7(1.5,2.0)$ & $1.8(1.6,2.1)$ \\
\hline
\end{tabular}







ranked first only slightly ahead of astrocytomas (IIIB), which was followed closely by medulloblastomas (IIIC1). For adolescents, germ cell tumors (XA) ranked a close second to astrocytomas (IIIB). Among teens, benign PCNST classified as other specified intracranial and intraspinal tumors (IIIE) were ranked first; the majority of patients in that sub-category were diagnosed specifically with pituitary adenoma (66.7\%). Overall, pituitary adenoma comprised $20.1 \%$ of all diagnoses in teens. In all age groups, the majority of tumors of uncertain behavior were classified as other specified intracranial and intraspinal tumors (IIIE) classification. In nearly every age group, the majority of those patients were diagnosed specifically with gangliogliomas, representing between 37.0\% (5-9 year olds) and 47.8\% (10-14 year olds) of those cases. Among children younger than 5 years old, nearly an equal number of patients were diagnosed with craniophargiomas and gangliogliomas (36.1 and 38.9\%, respectively).

Table 6 shows the distribution of astrocytomas; both malignant and benign numbered nearly the same for boys and girls younger than 15 years old, while among teens, they predominated in boys. Further, boys had the most ependymomas and choroid plexis tumors, medulloblastomas, and PNET. Although astrocytomas and PNET tumors were distributed nearly equally among non-Hispanic white and Hispanic children; all other histologies were more frequently seen in adolescent and teen non-Hispanic whites. In the low SES group, ependymomas and choroid plexis tumors, medulloblastomas, and PNET were found most often among children younger than 10 years old. Astrocytomas were found mostly among low SES children younger than 5, with a near even distribution among those 5-9 and among high SES adolescents and teens. Furthermore, benign astrocytomas were found mainly in the low SES group for children younger than 5 and in teens. In high SES groups however astrocytoma were found mainly among those 5-14 years old.

\section{Discussion}

This is the first study to examine both malignant and benign PCNST among children, adolescents, and teens in California. Fifty-three percent of PCNST among those younger than 20 years old were malignant, $33.3 \%$ benign, and the remainder was of uncertain behavior. The AAIR of malignant PCNST in this age group was 2.1 cases per 100,000 persons and for benign PCNST, 1.3 per 100,000. Among children and adolescents younger than 15 years old, the malignant PCNST was 2.2 per 100,000 and for benign PCNST, 1.2 per 100,000 .

In the present study, the incidence of malignant tumors decreased with increasing age. The highest incidence for malignant PCNST was found among children younger than 5 years old [8-11], whereas teens had the highest incidence of benign and uncertain behavior PCNST. Post-mortem studies on younger brains have found a higher relative concentration of neural stem cells [12,13], which suggests that the immature brain might possess an increased capacity to generate malignant neuroepithelial tumors through increased populations of neural stem and progenitor cell types, supporting the stem cell hypothesis for tumor formation [14].

Consistent with results found for adults, boys at every age group had a higher incidence of malignant tumors, while girls generally had a higher incidence of benign tumors $[11,15]$. Significant sex-specific differences were not found for malignant PCNST in the 5-9 year age group or for benign PCNST among adolescents. The incidence of malignant PCNST in girls dropped sharply starting in the 5-9 year old age group while the incidence of benign PCNST rose just as dramatically starting in the adolescence. Age- and sex-specific tumor frequency and tumor behavior transition are postulated to be hormone-related, coinciding with the onset of puberty, although the specific mechanism has yet to be determined [16]. For example, in a case report, the growth and regression of a pilocytic astrocytoma was found to be related to exogenous human growth hormone (hGH) [17].

In our study, astrocytomas were the prominent diagnoses for malignant PCNST in most age groups, which is consistent with other national and international studies $[8$, 10, 11, 15, 18-29]. Ependymomas and choroid plexus tumors were highest among children younger than 5 years old [19, 20, 26, 27], while other gliomas and medulloblastomas had a similar incidence to astrocytomas in the 59 age group [11,20]. We noted a surge in germ cell tumors for adolescents, which declined for teens concurrent with an increase in pituitary tumors $[16,30,31]$. The proportional incidence of pituitary adenomas in our study population was similar to that reported by CBTRUS, although our methods varied [21].

California's unique race/ethnic population allows analyses of the distribution of cancer incidence in groups that might otherwise be overlooked or inaccurately counted. California's younger population $(<20$ years old $)$ is predominantly Hispanic (45.8\%). Hispanics represent 50.2\% of children younger than 5 years old, $47.8 \%$ of those in the 5-9 age group, and $44.3 \%$ of the adolescent group. However, in the teen group, the Hispanic population is nearly equal to the non-Hispanic white population (40.9 and $39.5 \%$, respectively) [32]. Therefore not surprisingly, in our study the highest proportional incidence of malignant PCNST was among Hispanic children younger than 10 years old; non-Hispanic whites had the highest incidence among 10-19 year olds. The ASIR reported for 


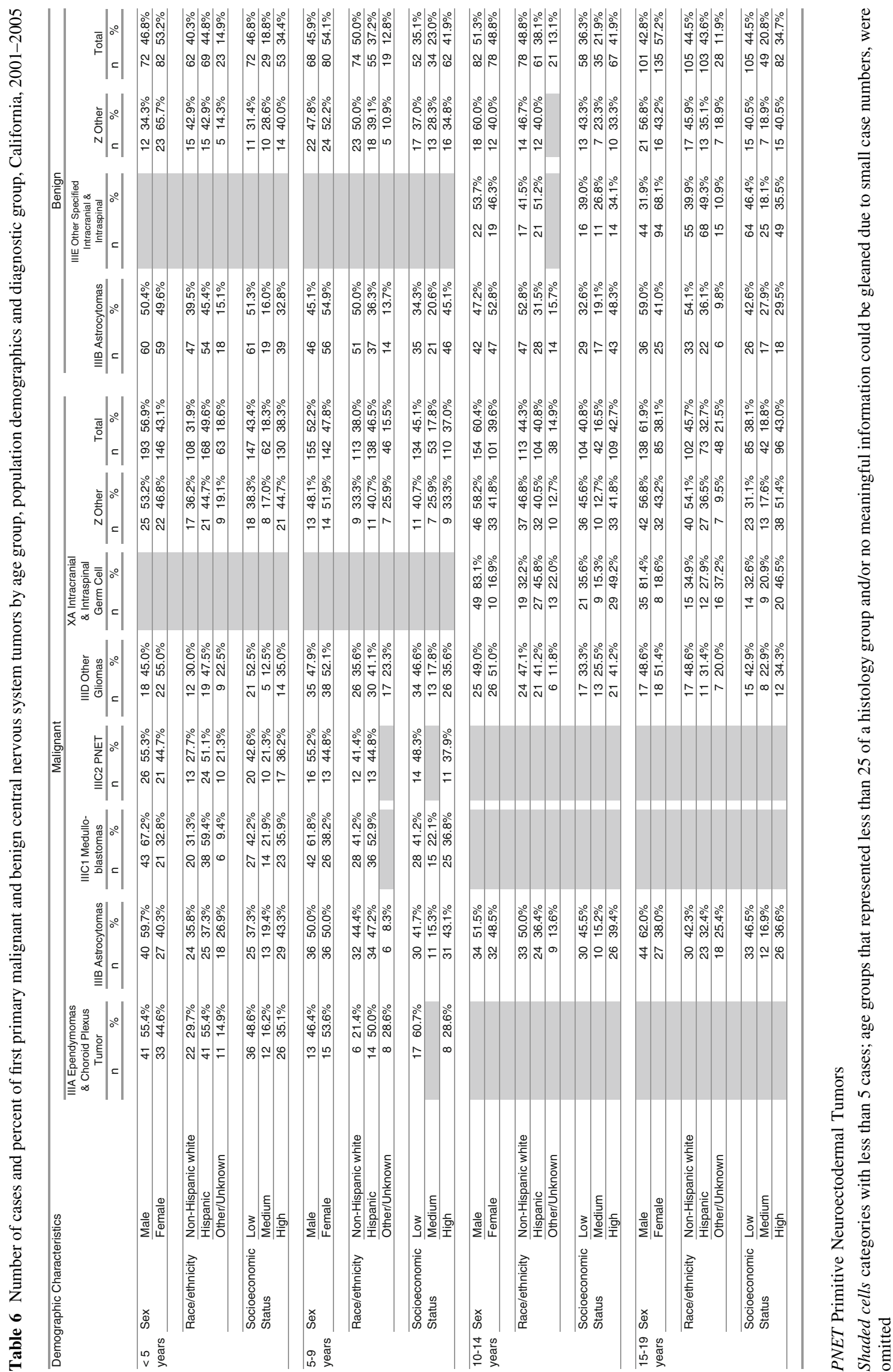


malignant PCNST for children younger than 5 (2.6-2.7 per 100,000) was nearly the same for Hispanics, non-Hispanic whites, and Asian/Pacific Islanders. Non-Hispanic whites had the highest incidence among 5-14 year olds (2.5 per $100,000)$ and Asian/Pacific Islanders had the highest incidence among teens $(2.3$ per 100,000$)$. The differences in these incidence rates were not statistically significant.

This is the first study to examine the proportions of PCNST incidence by SES in this age group. We found that children younger than 10 years old in the lowest SES group had a higher proportional incidence of malignant PCNST, while children and adolescents 5-19 years old in the highest SES group had a higher incidence of benign PCNST compared to other SES groups. This finding may be related to unique class level exposures or indirectly related to race/ethnicity population distribution, specifically those groups that are more likely at the lower SES levels and/or differential healthcare coverage [33]. Cancer incidence has been found to be highest among those with more education, greater income, and with private insurance $[34,35]$. Reasons for this are unclear. Some have advanced the theory, least in childhood leukemia, that higher SES groups are immunologically shielded by hyperhygienic environments, leading to naïve immune systems which are more prone to cancer development [36, 37].

Common causes for differences in CNS tumor incidence statistics between epidemiologic studies were discussed at length in the authors' companion publication in this edition. Unique to comparisons of pediatric CNS tumor incidence statistics is the variation in the selection of age groupings across sources and the use of the ICCC. The ICCC was designed specifically for childhood cancers and is based on tumor morphology in conjunction with primary anatomical site, rather than histology and anatomical site separately as is common [6, 7]. Additionally, SEER created a recode system for the ICCC [6, 7], as it did for the ICD-O [38]. The ICCC SEER site recode is used by the CCR, all North American central cancer registries, NPCR and SEER to organize histologies but not by CBTRUS or in international studies. Even when the ICCC was used, valid comparisons between studies and statistical sources could not be made because many of those studies used cases from a single institution or if population-based, did not calculate incidence rates [39-41]. When rates were available, the detail necessary for valid comparison was not the same [18, 42]. We found the use of the ICCC to have limitations. Although appropriate for showing transitioning tumor occurrence by age groups, the ICCC was inadequate for delineating PCNST among teens. For example, 20\% of benign PCNST among teens were pituitary adenomas, which were otherwise hidden in the category of "other intracranial and intraspinal", since they are nearly nonexistent among children and adolescents younger than 15 years old.
Our study's strengths and weakness have been discussed in the authors' companion publication in this edition. Specific to this study, even though 5 years of benign data had been collected, due to the small numbers of cases, stable and accurate incidence rates could not be calculated for many sex-race/ethnic-age group combinations among children, adolescents, and teens.

Primary central nervous system tumors are a major source of cancer morbidity and mortality among children, adolescents, and teens. While PCNST incidence has been relatively well-researched, this is the first study to comprehensively examine benign PCNST by ICCC diagnostic groups and age groups, and to compare them to malignant PCNST. In addition, this is one of the few studies to examine PCNST among adolescents [22, 24, 30, 43]. This study of California PCNST among children, adolescents, and teens provides a basis for future basic, translational and clinical brain tumor research and for both healthcare and public health in California.

Acknowledgements and disclaimer The collection of cancer incidence data used in this study was supported by the California Department of Public Health as part of the statewide cancer reporting program mandated by California Health and Safety Code Sect. 103885; the National Cancer Institute's Surveillance, Epidemiology and End Results Program under contract N01-PC-35136 awarded to the Northern California Cancer Center, contract N01-PC-35139 awarded to the University of Southern California, and contract N01PC-54404 awarded to the Public Health Institute; and the Centers for Disease Control and Prevention's National Program of Cancer Registries, under agreement 1U58DP00807-01 awarded to the Public Health Institute. The ideas and opinions expressed herein are those of the author(s) and endorsement by the State of California, Department of Public Health the National Cancer Institute, and the Centers for Disease Control and Prevention or their Contractors and Subcontractors is not intended nor should be inferred." The authors would like to thank Mark Allen, Research Scientist II and Winny Roshala, CTR, Quality Control Specialist II of the California Cancer Registry for their technical support; and Dr. Erica Whitney of the University of California, Davis and Cynthia Klutznick for their editorial guidance.

Open Access This article is distributed under the terms of the Creative Commons Attribution Noncommercial License which permits any noncommercial use, distribution, and reproduction in any medium, provided the original author(s) and source are credited.

\section{References}

1. Helman LJ, Malkin D Cancers of Childhood. In: DeVita VT, Lawrence TS, Rosenberg SA, DePinho RA, Weinberg RA (eds) DeVita, Hellman, and Rosenberg's Cancer: principles and practice of oncology. Lipponcott Williams \& Wilkins

2. California Cancer Registry (CCR): Brain and CNS Cancer Incidence, 2001-2005. SEER*Stat Database: Incidence-California, April 2008 (1988-2006), released April 2008. National Center for Health Statistics (NCHS) population estimates for 1990-2006; Benchmarked 1988-1989. California Department of Finance (DOF) population estimates July 2007. California Department of 
Public Health, Chronic Disease Surveillance and Research Section, generated by K. Bauer

3. Thuppal S, Propp JM, McCarthy BJ (2006) Average years of potential life lost in those who have died from brain and CNS tumors in the USA. Neuroepidemiology 27:22-27. doi: $10.1159 / 000093896$

4. California Assembly and Senate: California Health and Safety Code, Sections 103875-103885

5. California Assembly and Senate: California Health and Safety Code, Sect. $103885 \mathrm{H} 2$

6. SEER: SEER modification of the international classification of childhood cancer, third edition (ICCC-3)

7. Steliarova-Foucher E, Stiller C, Lacour B, Kaatsch P (2005) International classification of childhood cancer, third edition. Cancer 103:1457-1467. doi:10.1002/cncr.20910

8. Rickert CH, Probst-Cousin S, Gullotta F (1997) Primary intracranial neoplasms of infancy and early childhood. Childs Nerv Syst 13:507-513. doi:10.1007/s003810050127

9. Lannering B, Marky I, Nordborg C (1990) Brain tumors in childhood and adolescence in west Sweden 1970-1984. Epidemiology and survival. Cancer 66:604-609. doi:10.1002/ $1097-$

0142(19900801)66:3<604::AID-CNCR2820660334>3.0.CO;2-L

10. Farwell JR, Dohrmann GJ, Flannery JT (1977) Central nervous system tumors in children. Cancer 40:3123-3132. doi:10.1002/ 1097-0142(197712)40:6<3123::AID-CNCR2820400656>3.0. $\mathrm{CO} ; 2-6$

11. Yates AJ, Becker LE, Sachs LA (1979) Brain tumors in childhood. Childs Brain 5:31-39. doi:10.1159/000119799

12. Palmer TD, Schwartz PH, Taupin P, Kaspar B, Stein SA, Gage FH (2001) Cell culture. Progenitor cells from human brain after death. Nature 411:42-43. doi:10.1038/35075141

13. Schwartz PH, Bryant PJ, Fuja TJ, Su H, O'Dowd DK, Klassen H (2003) Isolation and characterization of neural progenitor cells from post-mortem human cortex. J Neurosci Res 74:838-851. doi:10.1002/jnr.10854

14. Singh SK, Hawkins C, Clarke ID, Squire JA, Bayani J, Hide T, Henkelman RM, Cusimano MD, Dirks PB (2004) Identification of human brain tumour initiating cells. Nature 432:396-401. doi: 10.1038 /nature 03128

15. Johannesen TB, Angell-Andersen E, Tretli S, Langmark F, Lote K (2004) Trends in incidence of brain and central nervous system tumors in Norway, 1970-1999. Neuroepidemiology 23:101-109. doi:10.1159/000075952

16. Jennings MT, Gelman R, Hochberg F (1985) Intracranial germcell tumors: natural history and pathogenesis. J Neurosurg 63:155-167

17. Connors MH, Boggan JE, Chong B, Kollipara S (1996) Expansion and shrinkage of central nervous system tumor coinciding with human growth hormone therapy: case report. Neurosurgery 39:1243-1245 discussion 1245-1246

18. Ries L, Melbert D, Stinchcomb DG, Howlader N, Horner MJ, Mariotto A, Miller BA, Feuer EJ, Altekruse SF, Lewis DR, Clegg L, Eisner MP, Reichman M, Edwards BK: SEER Cancer Statistics Review, 1975-2005. Cancer Statistics Branch, National Cancer Institute, Bethesda, MD

19. Gilles FH, Sobel EL, Tavare CJ, Leviton A, Hedley-Whyte ET (1995) Age-related changes in diagnoses, histological features, and survival in children with brain tumors: 1930-1979. The Childhood Brain Tumor Consortium. Neurosurgery 37:10561068. doi:10.1097/00006123-199512000-00004

20. Fleury A, Menegoz F, Grosclaude P, Daures JP, Henry-Amar M, Raverdy N, Schaffer P, Poisson M, Delattre JY (1997) Descriptive epidemiology of cerebral gliomas in France. Cancer 79:1195-1202. doi:10.1002/(SICI)1097-0142(19970315)79:6<11 95::AID-CNCR19>3.0.CO;2-V
21. CBTRUS statistical report: primary brain tumors in the United States, 2000-2004. Central Brain Tumor Registry of the United States, 2008

22. Ries L, Smith MA, Gurney JG, Tamara T, Young JL, Bunin GR (eds) (1999) Cancer incidence and survival among children and adolescents: United States SEER Program 1975-1995. National Cancer Institute, SEER Program. NIH Pub. No. 99-4649, Besthesda, MD

23. Tseng JH, Tseng MY (2006) Survival analysis of children with primary malignant brain tumors in England and Wales: a population-based study. Pediatr Neurosurg 42:67-73. doi:10.1159/ 000090458

24. Wu XC, Chen VW, Steele B, Roffers S, Klotz JB, Correa CN, Carozza SE (2003) Cancer incidence in adolescents and young adults in the United States, 1992-1997. J Adolesc Health 32:405415. doi:10.1016/S1054-139X(03)00057-0

25. Zhou D, Zhang Y, Liu H, Luo S, Luo L, Dai K (2008) Epidemiology of nervous system tumors in children: a survey of 1,485 cases in Beijing Tiantan Hospital from 2001 to 2005. Pediatr Neurosurg 44:97-103. doi:10.1159/000113110

26. Kadri H, Mawla AA, Murad L (2005) Incidence of childhood brain tumors in Syria (1993-2002). Pediatr Neurosurg 41:173177. doi:10.1159/000086557

27. Kaatsch P, Rickert CH, Kuhl J, Schuz J, Michaelis J (2001) Population-based epidemiologic data on brain tumors in German children. Cancer 92:3155-3164. doi:10.1002/1097-0142(20011 215) $92: 12<3155::$ AID-CNCR10158>3.0.CO;2-C

28. Swensen AR, Bushhouse SA (1998) Childhood cancer incidence and trends in Minnesota, 1988-1994. Minn Med 81:27-32

29. Miltenburg D, Louw DF, Sutherland GR (1996) Epidemiology of childhood brain tumors. Can J Neurol Sci 23:118-122

30. Lewis IJ (1996) Cancer in adolescence. Br Med Bull 52:887-897

31. Felix I, Becker LE (1990) Intracranial germ cell tumors in children: an immunohistochemical and electron microscopic study. Pediatr Neurosurg 16:156-162. doi:10.1159/000120517

32. U.S. Census Bureau: American Community Survey (2003) Summary tables. Generated by Monica Brown; using American FactFinder

33. U.S. Census Bureau Money Income (2005) In: Waldrop J (ed) Population profile of the United States. U.S. Government Printing Office, Washington, DC

34. Inskip PD, Tarone RE, Hatch EE, Wilcosky TC, Fine HA, Black PM, Loeffler JS, Shapiro WR, Selker RG, Linet MS (2003) Sociodemographic indicators and risk of brain tumours. Int $\mathrm{J}$ Epidemiol 32:225-233. doi:10.1093/ije/dyg051

35. Barker DJ, Weller RO, Garfield JS (1976) Epidemiology of primary tumours of the brain and spinal cord: a regional survey in southern England. J Neurol Neurosurg Psychiatr 39:290-296. doi: 10.1136/jnnp.39.3.290

36. Greaves M (2006) Infection, immune responses and the aetiology of childhood leukaemia. Nat Rev 6:193-203

37. Ribeiro KB, Buffler PA, Metayer C (2008) Socioeconomic status and childhood acute lymphocytic leukemia incidence in Sao Paulo, Brazil. Int J Cancer 123:1907-1912. doi:10.1002/ijc.23738

38. Fritz A, Percy C, Jack A, Shanmugaratnam K, Sobin L, Parkin DM, Whelan S (eds) (2000) International classification of diseases for oncology: ICD-O. World Health Organization, Geneva

39. Juarez-Ocana S, Gonzalez-Miranda G, Mejia-Arangure JM, Rendon-Macias ME, Martinez-Garcia Mdel C, Fajardo-Gutierrez A (2004) Frequency of cancer in children residing in Mexico City and treated in the hospitals of the Instituto Mexicano del Seguro Social (1996-2001). BMC Cancer 4:50. doi:10.1186/1471-2407-4-50

40. Becroft DM, Dockerty JD, Berkeley BB, Chan YF, Lewis ME, Skeen JE, Synek BJ, Teague LR (1999) Childhood cancer in New Zealand 1990 to 1993. Pathology 31:83-89. doi:10.1080/00313 0299105232 
41. Hung IJ, Yang CP, Jaing TH (2003) Patterns of cancer distribution in a medical center among adolescents 14 to 17 years of age for the period 1995 to 2001. J Formos Med Assoc 102:631-636

42. Michel G, von der Weid NX, Zwahlen M, Redmond S, Strippoli MP, Kuehni CE (2008) Incidence of childhood cancer in
Switzerland: the Swiss Childhood Cancer Registry. Pediatr Blood Cancer 50:46-51. doi:10.1002/pbc.21129

43. Stiller CA (2007) International patterns of cancer incidence in adolescents. Cancer Treat Rev 33:631-645. doi:10.1016/j.ctrv. 2007.01.001 